\title{
A possible link between the Epstein-Barr virus infection and autoimmune thyroid disorders
}

\author{
ANNA DITTFELD ${ }^{I}$, KATARZYNA GWIZDEK ${ }^{2}$, MAREK MICHALSKI ${ }^{1}$, ROMUALD WOJNICZ ${ }^{I}$ \\ ${ }^{1}$ Department of Histology and Embryology, School of Medicine with the Division of Dentistry, Medical University of Silesia, Zabrze, Poland \\ ${ }^{2}$ Department of Physiotherapy, School of Health Sciences, Medical University of Silesia in Katowice, Poland
}

\begin{abstract}
The Epstein-Barr virus (EBV), also known as human herpesvirus 4, is a member of the Herpesviridae virus family. EBV infection can cause infectious mononucleosis (IM) in the lytic phase of EBV's life cycle. Past EBV infection is associated with lymphomas, and may also result in certain allergic and autoimmune diseases. Although potential mechanisms of autoimmune diseases have not been clearly elucidated, both genetic and environmental factors, such as infectious agents, are considered to be responsible for their development. In addition, EBV modifies the host immune response. The worldwide prevalence of autoimmune diseases shows how common this pathogen is. Normally, the virus stays in the body and remains dormant throughout life. However, this is not always the case, and a serious EBV-related illness may develop later in life. This explains the chronic course of autoimmune diseases that is often accompanied by exacerbations of symptoms. Based on the present studies, EBV infection can cause autoimmune diseases, such as systemic lupus erythematosus (SLE), multiple sclerosis (MS), rheumatoid arthritis (RA), Sjögren's syndrome, and autoimmune hepatitis. The EBV has also been reported in patients with autoimmune thyroid disorders. Although EBV is not the only agent responsible for the development of autoimmune thyroid diseases, it can be considered a contributory factor.
\end{abstract}

Key words: autoimmunity, Epstein-Barr virus, autoimmune thyroid disorders.

(Cent Eur J Immunol 2016; 41 (3): 297-301)

\section{Epstein-Barr virus: biology and disease}

The Epstein-Barr virus (EBV) is a member of the Herpesviridae virus family. Human beings are the primary reservoir for EBV. Its main targets are B-lymphocytes and nasopharyngeal epithelial cells. It is estimated that the incidence of EBV infection among adults is between $90 \%$ and $95 \%$. The EBV's life cycle is divided into the lytic and latent phases [1]. Most infections are symptomless [2]. However, it is evident that EBV may cause infectious mononucleosis (IM) in the lytic phase of EBV's life cycle. Past EBV infection is associated with Burkitt lymphoma, Hodgkin disease, and nasopharyngeal or stomach cancer [1]. In addition, there is a hypothesis that past EBV infection can also lead to certain allergic and autoimmune diseases [1]. Once a person has been infected with EBV, she or he will carry EBV latent infection of B-lymphocytes [3]. Viral load remains relatively constant over time in circulating B-cells with a non-activated phenotype [4]. However, during the latent phase, $\mathrm{EBV}$ reactivation is possible. It can be caused by either immunosuppression, certain cytokines, or steroid hormones [1].

\section{Infectious agents and autoimmunity}

Although potential mechanisms of autoimmune diseases have not been clearly elucidated, both genetic and environmental factors, such as infectious agents, are considered to be responsible for their development [5]. The microbial agents include viruses, bacteria, fungi, and parasites [6].

Also, five possible mechanisms for the pathogenesis of autoimmune diseases have been distinguished:

- molecular mimicry - activation of autoreactive T cells by microbial peptides with structural similarity to self-peptides;

- viral and bacterial superantigens - activation of autoreactive $\mathrm{T}$ cells that express particular $\mathrm{V} \beta$ segments;

- enhanced processing and presentation of auto-antigens by antigen-presenting cells recruited to an inflammatory site and followed by autoreactive lymphocyte priming;

Correspondence: Anna Dittfeld, PhD, Department of Histology and Embryology, School of Medicine with the Division of Dentistry,

Medical University of Silesia, Jordana 19, 41-808 Zabrze, Poland, e-mail: annadittfeld@ gmail.com

Submitted: 25.05.2016; Accepted: 21.06.2016 
- bystander activation - enhanced cytokine production that induces the expansion of autoreactive T cells;

- activation of lymphocytes by lymphotropic viruses - an infection of B cells resulting in B cell proliferation, excess antibody production, and formation of circulating immune complexes [6,7].

\section{The role of the Epstein-Barr virus in autoimmunisation}

Epstein-Barr virus is considered to be an aetiological factor of autoimmune diseases because of the following:

- the virus is a common pathogen responsible for the worldwide prevalence of autoimmune diseases;

- EBV stays in the body throughout life, which explains the chronic course of autoimmune diseases that are often accompanied by exacerbations of symptoms;

- the virus modifies the host immune response [5].

Epstein-Barr virus shows immunomodulatory effects. It encodes a homolog of the bcl-2 oncogene that inhibits apoptosis and interferon $\gamma(\mathrm{IFN}-\gamma)$ signaling in B-cells. It is also responsible for changes in the production of pro-inflammatory cytokines, such as tumor necrosis factor $\alpha$ (TNF- $\alpha$ ), interleukin (IL)-1, and IL-6, as well as of viral cytokines that share immunosuppressive properties with IL-10 [8, 9]. Interleukin 10 intensifies Bcl-2 expression and reduces IFN- $\gamma$ production [10]. Interleukin 1 , TNF- $\alpha$, and IFN- $\gamma$ can induce HLA class II expression and lead to auto-antigen presentation and auto-reactive T-cell activation [11]. The Epstein-Barr virus can also infect T lymphocytes [12].

In 1971, Evan demonstrated raised antibody titres to EBV in patients with systemic lupus erythematosus (SLE). This was the reason to suspect that the EBV might participate in the development of autoimmune diseases [13]. Moreover, there is now evidence that EBV infection can cause autoimmune diseases, for example SLE [13, 14], multiple sclerosis (MS) [15], rheumatoid arthritis (RA) [16], Sjögren's syndrome [17, 18], or autoimmune hepatitis [19]. Several mechanisms of autoimmunity have been shown to be involved in the pathogenesis of these diseases. As far as lupus erythematosus is concerned, these are: high EBV DNA viral loads, elevated EBV antibody concentrations, impaired EBV-specific T-cell responses, and the phenomenon of molecular mimicry [5, 20]. For rheumatoid arthritis, they include: high anti-EBV titres, cell-mediated control of EBV, cross-reactivity between EBV and human self-proteins (molecular mimicry), presence of the EBV genome in synovial membrane, and a cell-mediated response to the EBV within the joint [21]. For primary Sjögren's syndrome (pSS), they are: more frequent presence of EBV DNA in saliva and salivary tissue, as well as an elevated level of anti-EBV titres [22]. Patients with infectious mononucleosis have been reported with various antibodies in their serum. This can also suggest that there is a link between the EBV infection and autoimmune diseases [23].

\section{Aetiology of autoimmune thyroid disorders}

Autoimmune thyroid disorders (AITDs) are the most common organ-specific autoimmune diseases [24]. They affect up to $10 \%$ of the world's population [25]. Autoimmune thyroid disorders develop upon activation of specific helper T cells directed against the thyroid antigens, the thyroid peroxidase (TPO), and the thyrotropin receptor (TSHR). Activated helper T cells induce B cells to secrete thyroid antibodies, such as the thyroid peroxidase antibodies (TPOAbs) and the thyrotropin receptor antibodies (TRAbs) [26].

Family clustering of these disorders may provide evidence for their genetic and environmental aetiology [27]. According to Hansen, between $60 \%$ and $70 \%$ of autoimmune thyroid disorders are genetic-related [28]. Environmental factors are also said to play a role in AITDs, accounting for $20-40 \%$ of cases with regard to monozygous twins [29]. Other factors that are also considered to be responsible for autoimmune thyroid disorders include: irradiation, treatment with radioiodine, iodine or iodine-rich amiodarone, selenium intake, hormones, oral contraceptives, drugs, antiretrovirals, pregnancy and/or parity, stress, direct trauma, seasonal variation, smoking, campath- $1 \mathrm{H}$ anti-CD52, IFN- $\gamma$, IL-2, granulocyte-macrophage colony-stimulating factor (GM-CSF), viral and/or bacterial infections, and lack of infections (the hygiene hypothesis) [27, 30].

The morbidity rate for Graves' disease is increased in spring and summer. This confirms an infectious aetiology of the disorders [31]. To be specific, thyrocytes express a functional toll-like receptor 3 (TLR3) which, when overexpressed, may cause Hashimoto's thyroiditis (HT) that can be induced by a virus infection [32].

Penhale and Young have demonstrated that rats that have undergone both thymectomy and irradiation are less susceptible to AITDs if maintained under specific pathogen-free conditions [33]. In 1983, Carter and Smith infected chicken embryos with an avian leukosis virus, RAV-7. As a result, the chickens became hypothyroid [34]. Based on these results, infections may either induce or exacerbate autoimmune thyroid disorders [27]. Wolf found that infections with Yersinia enterocolitica could be linked to Graves' disease [35]. Tozolli, in turn, has suggested that Toxoplasma gondii may participate in AITDs [26]. In a study by Wasserman, it was shown that prior infection with Toxoplasma gondii can be closely associated with elevated thyroid peroxidase antibodies [36].

In addition, researchers have shown that HTLV-1 may have an impact on the development of both Hashimoto's thyroiditis [37, 38] and Graves' disease [39]. Other studies have found that there is a possible link between HIV infection and autoimmune thyroid disorders [40, 41]. Also, 
human foamy virus (HFV) proteins have been detected in the thyroid tissue of patients with Graves' disease [42].

Serological data indicates that the influenza virus, hepatitis $\mathrm{C}$ virus, enterobacteriaceae, streptococci, staphylococci, Yersinia, and Helicobacter can have an influence on AITDs as well [26, 42]. Nevertheless, conflicting data has also been published with regard to the rubella virus, the parvovirus, as well as hepatitis $\mathrm{B}$ and $\mathrm{C}$ viruses [43].

\section{Epstein-Barr virus as an aetiological factor in autoimmune thyroid disorders}

In one study, thyroid tissue specimens obtained from AITD patients and patients with multinodular goitre have been investigated to detect Herpesviridae DNA. The group of AITD patients have been reported with Herpesviridae DNA more frequently than the other group. However, there was no statistical significance observed in AITD patients, nor in patients with any other viruses [44].

There is a hypothesis that in genetically susceptible patients, EBV-infected autoreactive B-cells seed the thyroid gland, produce autoantibodies, and send co-stimulatory signals to autoreactive T-cells [45]. Normally, the EBV infection is kept under control, especially by cytotoxic CD8+ T-cells that eliminate proliferating and lytically infected B-cells [46]. Impaired EBV control may result from a decreased number of EBV-specific CD8+ T-cells. An increased $\mathrm{CD} 4 / \mathrm{CD} 8$ ratio is characteristic of autoimmune diseases [45].

In their study, Akahori et al. presented three cases of patients suffering from Graves' disease comorbid with infectious mononucleosis due to primary EBV infection [47]. They suggested that inflammation from viral infection might be associated with the development of Graves' disease [47].

Nagata has shown that in vitro reactivation of the EBV infection causes the production of thyrotropin receptor antibodies (TRAbs) in EBV-infected B-cells with TRAbs on their surface [48]. Moreover, Nagata has also reported increased TRAb titres in children with infectious mononucleosis due to EBV primary infection [23].

In a study by Janegova, subjects with Hashimoto's thyroiditis were reported with latent membrane protein 1 (LMP1), which was not revealed in the case of Graves' disease patients. Epstein-Barr virus-encoded small RNAs (EBERs) were detected in both Hashimoto's thyroiditis and Graves' disease patients, exclusive of negative control samples [25].

In addition, an elevated serum level of Epstein-Barr nuclear antigen (EBNA) was observed in patients with Hashimoto's thyroiditis [49]. Also, it was found that antibodies against EBV viral capsid antigen (IgG-VCA) and against early antigen (IgG-EA-D/DR) were more common for patients with thyroiditis versus the controls [49]. The seroprevalence of EBV infection was reported to be higher in children with autoimmune thyroid disorders when compared to the controls [50]. However, Tozzoli failed to observe elevated EBV-IgG levels in AITD patients when compared to the healthy controls [26].

It is said that thyroid autoantibodies occur more frequently in subjects with autoimmune diseases versus the general population [24]. Experts suggest that thyroid function screening should be conducted in patients with primary Sjögren's syndrome, rheumatoid arthritis, and lupus erythematosus [24] because these diseases may be connected with EBV infection.

The EBV can lead to in vitro transformation of normal resting B lymphocytes to proliferating lymphoblasts [12]. Moreover, the virus can be found in many lymphomas [51] Therefore, researchers suggest that EBV may participate in the malignant transformation of Hashimoto's disease into malignant lymphoma of the thyroid [52] (Table 1). Over $90 \%$ of all primary thyroid lymphomas are diagnosed in individuals with a history of Hashimoto's disease [53], and the majority of them are of B-cell origin [12].

Table 1. A possible link between the Epstein-Barr virus (EBV) infection and autoimmune thyroid disorders (AITD) according to literature

\begin{tabular}{l}
\hline AITD patients have been more frequently reported with Herpesviridae DNA \\
\hline Graves' disease coexisted with infectious mononucleosis due to primary EBV infection \\
\hline Increased TRAb titres in children with infectious mononucleosis due to EBV primary infection were observed \\
\hline In vitro reactivation of the Epstein-Barr virus infection caused the production of TRAbs in EBV-infected B-cells with TRAbs on their \\
surface \\
\hline Subjects with Hashimoto's thyroiditis were reported with latent membrane protein 1 (LMP1) \\
\hline EBERs were detected in Hashimoto's thyroiditis and Graves' disease patients \\
\hline Elevated serum level of Epstein-Barr nuclear antigen (EBNA) was observed in patients with Hashimoto's thyroiditis \\
\hline IgG-VCA and IgG-EA-D/DR were more common for patients with thyroiditis \\
\hline
\end{tabular}




\section{Conclusions}

Based on the study results, EBV is not the only agent responsible for the development of autoimmune thyroid diseases. However, it can be considered a contributory factor. Further investigations still need to be undertaken to explain the link between the EBV infection and autoimmune thyroid disorders.

\section{The authors declare no conflict of interest.}

\section{References}

1. Bocian J, Januszkiewicz-Lewandowska D (2011): Zakażenia EBV - cykl życiowy, metody diagnostyki, chorobotwórczość. Postepy Hig Med Dosw (Online) 65: 286-298.

2. Piecyk-Sidor M, Polz-Dacewicz MA (2005): Ocular involvement in Epstein-Barr virus infection. Postepy Hig Med Dosw (Online) 59: 602-607.

3. Crawford DH (2001): Biology and disease associations of Epstein-Barr virus. Philos Trans R Soc Lond B Biol Sci 356: 461-473.

4. Miyashita EM, Yang B, Lam KM, et al. (1995): A novel form of Epstein-Barr virus latency in normal B cells in vivo. Cell 80: 593-601.

5. Toussirot E, Roudier J (2008): Epstein-Barr virus in autoimmune diseases. Best Pract Res Clin Rheumatol 22: 883-896.

6. Barzilai O, Sherer Y, Ram M, et al. (2007): Epstein-Barr virus and cytomegalovirus in autoimmune diseases: are they truly notorious? A preliminary report. Ann N Y Acad Sci 1108: 567577.

7. Wucherpfennig KW (2001): Mechanisms for the induction of autoimmunity by infectious agents. J Clin Invest 108: 1097 1104.

8. Lotz M, Roudier J (1989): Epstein-Barr virus and rheumatoid arthritis: cellular and molecular aspects. Rheumatol Int 9: 147152.

9. Kanegane H, Wakiguchi H, Kanegane C, et al. (1997): Viral interleukin-10 in chronic active Epstein-Barr virus infection. J Infect Dis 176: 254-257.

10. Szmidt A, Stańczyk-Przyłuska A (2005): Rola wirusa EBV w patogenezie chorób alergicznych. Alergia Astma Immmunologia 4: 169-174.

11. Tomer Y, Davies TF (1993): Infection, thyroid disease, and autoimmunity. Endocr Rev 14: 107-120.

12. Kasprzak A, Spachacz R, Wachowiak J, et al. (2007): Epstein-Barr virus (EBV) infection in B-cell non-Hodgkin's lymphomas in children: virus latency and its correlation with CD21 and CD23 molecules. Folia Histochem Cytobiol 45: 169-179.

13. Evans AS, Rothfield NF, Niederman JC (1971): Raised antibody titres to E.B. virus in systemic lupus erythematosus. Lancet 1: 167-168.

14. James JA, Kaufman KM, Farris AD, et al. (1997): An increased prevalence of Epstein-Barr virus infection in young patients suggests a possible etiology for systemic lupus erythematosus. J Clin Invest 100: 3019-3026.

15. Fernández-Menéndez S, Fernández-Morán M, Fernández-Vega I, et al. (2016): Epstein-Barr virus and multiple sclerosis. From evidence to therapeutic strategies. J Neurol Sci 361: 213-219.

16. Ball RJ, Avenell A, Aucott L, et al. (2015): Systematic review and meta-analysis of the sero-epidemiological association be- tween Epstein-Barr virus and rheumatoid arthritis. Arthritis Res Ther 17: 274.

17. Kivity S, Arango MT, Ehrenfeld M, et al. (2014): Infection and autoimmunity in Sjogren's syndrome: a clinical study and comprehensive review. J Autoimmun 51: 17-22.

18. Fox RI, Pearson G, Vaughan JH (1986): Detection of Epstein-Barr virus-associated antigens and DNA in salivary gland biopsies from patients with Sjogren's syndrome. J Immunol 137: 3162-3168.

19. Vento S, Guella L, Mirandola F, et al. (1995): Epstein-Barr virus as a trigger for autoimmune hepatitis in susceptible individuals. Lancet 346: 608-609.

20. Tsokos GC, Magrath IT, Balow JE (1983): Epstein-Barr virus induces normal B cell responses but defective suppressor $\mathrm{T}$ cell responses in patients with systemic lupus erythematosus. J Immunol 131: 1797-1801.

21. Toussirot E, Roudier J (2007): Pathophysiological links between rheumatoid arthritis and the Epstein-Barr virus: an update. Joint Bone Spine 74: 418-426.

22. Fox RI, Luppi M, Pisa P, Kang HI (1992): Potential role of Epstein-Barr virus in Sjogren's syndrome and rheumatoid arthritis. J Rheumatol Suppl 32: 18-24.

23. Nagata K, Okuno K, Ochi M, et al. (2015): Production of thyrotropin receptor antibodies in acute phase of infectious mononucleosis due to Epstein-Barr virus primary infection: a case report of a child. Springerplus 4: 456.

24. Juszkiewicz A, Tłustochowicz W (2011): Prevalence of antithyroid antibodies and thyroid dysfunction in selected rheumatic diseases. Reumatologia 49: 132-137.

25. Janegova A, Janega P, Rychly B, et al. (2015): The role of Epstein-Barr virus infection in the development of autoimmune thyroid diseases. Endokrynol Pol 66: 132-136.

26. Tozzoli R, Barzilai O, Ram M, et al. (2008): Infections and autoimmune thyroid diseases: parallel detection of antibodies against pathogens with proteomic technology. Autoimmun Rev 8: 112-115.

27. Davies TF (2008): Infection and autoimmune thyroid disease. J Clin Endocrinol Metab 93: 674-676.

28. Hansen PS, Brix TH, Iachine I, et al. (2006): The relative importance of genetic and environmental effects for the early stages of thyroid autoimmunity: a study of healthy Danish twins. Eur J Endocrinol 154: 29-38.

29. Brix TH, Christensen K, Holm NV, et al. (1998): A population-based study of Graves' disease in Danish twins. Clin Endocrinol (Oxf) 48: 397-400.

30. Kondrashova A, Viskari H, Haapala AM, et al. (2008): Serological evidence of thyroid autoimmunity among schoolchildren in two different socioeconomic environments. J Clin Endocrinol Metab 93: 729-734.

31. Misaki T, Iida Y, Kasagi K, Konishi J (2003): Seasonal variation in relapse rate of graves' disease after thionamide drug treatment. Endocr J 50: 669-672.

32. Harii N, Lewis CJ, Vasko V, et al. (2005): Thyrocytes express a functional toll-like receptor 3: overexpression can be induced by viral infection and reversed by phenylmethimazole and is associated with Hashimoto's autoimmune thyroiditis. Mol Endocrinol 19: 1231-1250.

33. Penhale WJ, Young PR (1988): The influence of the normal microbial flora on the susceptibility of rats to experimental autoimmune thyroiditis. Clin Exp Immunol 72: 288-292.

34. Carter JK, Smith RE (1983): Rapid induction of hypothyroidism by an avian leukosis virus. Infect Immun 40: 795-805. 
35. Wolf MW, Misaki T, Bech K, et al. (1991): Immunoglobulins of patients recovering from Yersinia enterocolitica infections exhibit Graves' disease-like activity in human thyroid membranes. Thyroid 1: 315-320.

36. Wasserman EE, Nelson K, Rose NR, et al. (2009): Infection and thyroid autoimmunity: A seroepidemiologic study of TPOaAb. Autoimmunity 42: 439-446.

37. Kawai H, Inui T, Kashiwagi S, et al. (1992): HTLV-I infection in patients with autoimmune thyroiditis (Hashimoto's thyroiditis). J Med Virol 38: 138-141.

38. Akamine H, Takasu N, Komiya I, et al. (1996): Association of HTLV-I with autoimmune thyroiditis in patients with adult T-cell leukaemia (ATL) and in HTLV-I carriers. Clin Endocrinol (Oxf) 45: 461-466.

39. Matsuda T, Tomita M, Uchihara JN, et al. (2005): Human T cell leukemia virus type I-infected patients with Hashimoto's thyroiditis and Graves' disease. J Clin Endocrinol Metab 90: 5704-5710.

40. Zandman-Goddard G, Shoenfeld Y (2002): HIV and autoimmunity. Autoimmun Rev 1: 329-337.

41. Drabick JJ, Horning VL, Lennox JL, et al. (1991): A retrospective analysis of diseases associated with indeterminate HIV western blot patterns. Mil Med 156: 93-96.

42. Wick G, Grubeck-Loebenstein B, Trieb K, et al. (1992): Human foamy virus antigens in thyroid tissue of Graves' disease patients. Int Arch Allergy Immunol 99: 153-156.

43. Desailloud R, Hober D (2009): Viruses and thyroiditis: an update. Virol J 6: 5.

44. Thomas D, Liakos V, Michou V, et al. (2008): Detection of herpes virus DNA in post-operative thyroid tissue specimens of patients with autoimmune thyroid disease. Exp Clin Endocrinol Diabetes 116: 35-39.

45. Pender MP (2012): CD8+ T-cell deficiency, Epstein-Barr virus infection, vitamin $\mathrm{D}$ deficiency, and steps to autoimmunity: a unifying hypothesis. Autoimmune Dis 2012: 189096.

46. Hislop AD, Taylor GS, Sauce D, Rickinson AB (2007): Cellular responses to viral infection in humans: lessons from Epstein-Barr virus. Annu Rev Immunol 25: 587-617.

47. Akahori H, Takeshita Y, Saito R, et al. (2010): Graves' disease associated with infectious mononucleosis due to primary Epstein-Barr virus infection: report of 3 cases. Intern Med 49: 2599-2603.

48. Nagata K, Nakayama Y, Higaki K, et al. (2015): Reactivation of persistent Epstein-Barr virus (EBV) causes secretion of thyrotropin receptor antibodies (TRAbs) in EBV-infected B lymphocytes with TRAbs on their surface. Autoimmunity 48: 328-335.

49. Vrbikova J, Janatkova I, Zamrazil V, et al. (1996): Epstein-Barr virus serology in patients with autoimmune thyroiditis. Exp Clin Endocrinol Diabetes 104: 89-92.

50. Thomas D, Karachaliou F, Kallergi K, et al. (2008): Herpes virus antibodies seroprevalence in children with autoimmune thyroid disease. Endocrine 33: 171-175.

51. Lam KY, Lo CY, Kwong DL, et al. (1999): Malignant lymphoma of the thyroid. A 30-year clinicopathologic experience and an evaluation of the presence of Epstein-Barr virus. Am J Clin Pathol 112: 263-270.

52. Takahashi K, Kashima K, Daa T, et al. (1995): Contribution of Epstein-Barr virus to development of malignant lymphoma of the thyroid. Pathol Int 45: 366-374.

53. Watanabe N, Noh JY, Narimatsu H, et al. (2011): Clinicopathological features of 171 cases of primary thyroid lymphoma: a long-term study involving 24553 patients with Hashimoto's disease. Br J Haematol 153: 236-243. 